Review

\title{
Where's Waldo? Extrahepatic Site Options for Islet Transplantation
}

Alexandria J Coughlan ${ }^{1}$, Kendall R. McEachron ${ }^{1}$, Mariya E. Skube ${ }^{1}$, Sydne Muratore ${ }^{1}$, Melena D. Bellin ${ }^{2,3}$, Greg J Beilman ${ }^{1, *}$

1. Department of Surgery, University of Minnesota Medical School, Minneapolis, MN, USA; EMails: $\quad$ cough083@umn.edu; Kendallm@umn.edu; sydne.clark@gmail.com; hache005@umn.edu; beilman@umn.edu

2. Department of Medicine, University of Minnesota Medical School, Minneapolis, MN, USA; EMail: bell0130@umn.edu

3. Department of Pediatrics, University of Minnesota Medical School, Minneapolis, MN, USA.

* Correspondence: Gregory Beilman; E-Mail: beilman@umn.edu

Academic Editor: Yasuhiko Sugawara

Special Issue: Current Advancement of Islet Cell Transplantation in the Treatment of Diabetes Mellitus

OBM Transplantation

2019 , volume 3 , issue 1

doi:10.21926/obm.transplant.1901042
Received: October 29, 2018

Accepted: January 22, 2019

Published: January 24, 2019

\begin{abstract}
The current predominant location for allo- and auto-transplantation of islets is the liver. Despite the historical success of this site, recent studies have revealed multiple disadvantages. Portal hypertension, portal vein thrombosis, bleeding, low oxygen tension, instant blood mediated inflammatory reaction, inadequate alpha cell function, and delays in neovascularization are factors that continue to drive researchers to explore alternative sites for islet transplantation. Factors of an optimal site include: capacity, transplant efficacy, portal venous drainage, high oxygen tension, and easy retrievability. Sites such as the spleen, kidney, intestinal wall, bone marrow, omentum, and peritoneum, among others, have been evaluated for islet transplant. The various benefits and limitations of these alternate sites are reviewed in this article.
\end{abstract}

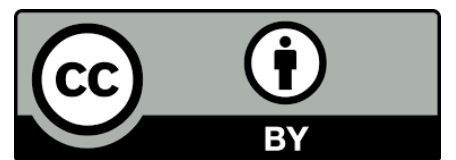

(C) 2019 by the author. This is an open access article distributed under the conditions of the Creative Commons by Attribution License, which permits unrestricted use, distribution, and reproduction in any medium or format, provided the original work is correctly cited. 


\section{Keywords}

Extrahepatic; islet transplantation; alternative islet transplantation sites

\section{Introduction}

The indications and methods for islet transplantation have developed over a period of almost 50 years, since it was first performed in the 1970s [1]. Islets can be transplanted as allografts or autografts. In allotransplantation, a smaller purified volume of islets from a cadaveric donor is administered, and immunosuppression is required to prevent rejection. Allografts are used in patients with type 1 diabetes and are considered to be a promising method of treatment (citregistry.org). Autografts after typically performed after pancreatectomy to prevent pancreatogenic diabetes and do not require immunosuppression as patients are receiving their own islets.

Islet autotransplantation is used in the treatment of chronic pancreatitis in patients for whom medical therapy has failed. Endoscopic procedures are the first-line therapy but frequently this is insufficient to address the life altering pain associated with this condition. Given the lack of substantive medical therapies, surgical interventions are often the next step. Total pancreatectomy with islet autotransplantation (TPIAT) is utilized to remove the source of the pain while salvaging the patient's functional islets. Total pancreatectomy in isolation could condemn a patient to a life with brittle type $3 c$ diabetes; thus, the autologous islets are isolated through a combination of enzymatic and mechanical means from the resected pancreas and then infused into the portal vein [2].

Historically, the liver has been the predominant site for both allo and auto islet transplantation. However, there is an increasing body of evidence suggesting that there are site-specific factors that impact engraftment and lead to attrition of islets over time [3]. The characteristics that make intraportal infusion an ideal method along with its many limitations are discussed in this paper. Because of the limitations of the liver site, there has been a resurgence of study into alternative, extrahepatic sites of transplantation (Table 1). This article reviews extrahepatic sites, including those that at this time are purely experimental, as well as those with clinical application seen in case series and ongoing clinical trials.

\section{Intraportal Infusion of Islet Cells}

Traditionally, islets have been infused into the liver given the ease of access to the portal or mesenteric veins intraoperatively after total pancreatectomy or through a percutaneous approach for allotransplants. Also, the path of the endocrine hormones mirrors where they would typically be released from the pancreas into the portal system, avoiding the resulting hyperinsulinemia associated with systemic drainage seen in other transplant sites [4-5]. Additionally, insulin is largely metabolized in the liver (80\%), and a 2006 study demonstrated that patients with type 1 diabetes mellitus with liver autografts had similar hepatic metabolization to controls [6].

This practice started after a study of streptozosin-induced diabetic rats demonstrated better glycemic control with significantly less islets needed when infused into the portal vein compared 
to the peritoneal or subcutaneous spaces [1]. The first cases of post-islet transplant insulin independence, in patients with type 1 diabetes and in patients who received an autoislet transplant after pancreatectomy for chronic pancreatitis, cemented intraportal infusion as the designated path for islet transplantation [7, 8]. As a result, the liver as a site for transplant has been extensively studied in both preclinical and clinical settings. Subsequently, the vast majority of clinical experience with islet transplantation has been via intraportal infusion, with important standardizations of treatment such as the use of multiple donors and the Edmonton protocol [9]. Some of the benefits and limitations of this site are documented in Figure 1.

Table 1 Type of evidence currently available by site.

\begin{tabular}{|l|l|l|l|l|l|}
\hline Site of Transplant* & Rodent & Pig & Canine & Non-human primate & Human \\
\hline Liver & $\mathrm{x}$ & $\mathrm{x}$ & $\mathrm{x}$ & $\mathrm{x}$ & $\mathrm{x}$ \\
\hline Spleen & $\mathrm{x}$ & $\mathrm{x}$ & $\mathrm{x}$ & $\mathrm{x}$ & $\mathrm{x}$ \\
\hline Kidney & $\mathrm{x}$ & $\mathrm{x}$ & $\mathrm{x}$ & $\mathrm{x}$ & $\mathrm{x}$ \\
\hline Bone Marrow & $\mathrm{x}$ & & & $\mathrm{x}$ & $\mathrm{x}$ \\
\hline Omentum & $\mathrm{x}$ & $\mathrm{x}$ & $\mathrm{x}$ & $\mathrm{x}$ & $\mathrm{x}$ \\
\hline Peritoneum & $\mathrm{x}$ & & $\mathrm{x}$ & $\mathrm{x}$ & $\mathrm{x}$ \\
\hline Muscle & $\mathrm{x}$ & $\mathrm{x}$ & $\mathrm{x}$ & & $\mathrm{x}$ \\
\hline Subcuticular & $\mathrm{x}$ & & & & $\mathrm{x}$ \\
\hline Intestinal Wall & $\mathrm{x}$ & $\mathrm{x}$ & $\mathrm{x}$ & & $\mathrm{x}$ \\
\hline
\end{tabular}

\begin{tabular}{ll}
\hline Benefits & Limitations \\
\hline Mimics portal drainage of the pancreas & IBMIR \\
Easy access intraoperatively or percutaneously & $\begin{array}{l}\text { Technical: PVT, bleeding, portal } \\
\text { hypertension }\end{array}$ \\
Proven beta cell efficacy & $\begin{array}{l}\text { Immunologic concerns } \\
\text { Can accommodate large volumes }\end{array}$ \\
Similar metabolism of insulin as the pancreas & $\begin{array}{l}\text { Microenvironment concerns } \\
\text { Difficult site to study postoperatively }\end{array}$ \\
\end{tabular}

IBMIR: Instant Blood Mediated Inflammatory Reaction, PVT: Portal Vein Thrombosis

Figure 1 Benefits and limitations of intraportal infusion of islets. 


\section{Immunologic and Inflammatory Disadvantages to Intraportal Infusion}

Islets are not exposed directly to blood in the native pancreas. Whether an auto- or allogenic transplant is being performed, contact with blood during infusion of islets causes a process known as instant blood-mediated inflammatory reaction (IBMIR) to occur [10]. This reaction activates both the complement and coagulation cascades. These processes ultimately culminate in islet apoptosis. Studies have shown loss of up to $50 \%$ of islets within the first hours post-transplant, as demonstrated by acute C-peptide release and quantitative PET imaging [10].

In allotransplants there are additional immunologic and inflammatory challenges. The liver is rich in Kupffer cells which may prompt an acute nonspecific cell-mediated inflammatory reaction leading to graft loss. Liver natural killer (NK) cells may also contribute to early graft loss [11]. Finally, immunosuppressive medications are toxic to islets, limiting beta cell viability and revascularization [12]; the blood concentration of such drugs is high in the portal vein given the first pass effect [13].

\section{Anatomic and Physiologic Disadvantages to Intraportal Infusion}

Blood oxygen tension in the portal venous system is less than a third of that of the pancreas. In the native pancreas, islets are typically maintained at an arterial oxygen tension of $40 \mathrm{mmHg}$ [14]. The islets become devascularized during the isolation process. As the islets engraft into the hepatic parenchyma the process of neovasculariazation from the hepatic arterial system takes 714 days, and until that time the islets are oxygenated via diffusion in the low oxygen tension of the portal venous system (pO2 10-15 mmHg). It has been demonstrated that islets continue to have a low oxygen tension of $5 \mathrm{mmHg}$ for up to three months post-transplant [15]. Although, the low oxygen tension of the islets persists in other sites despite their better tissue oxygenation; thus, the intraportal location may not be entirely to blame [14].

Furthermore, portal vein manipulation can also lead to potential complications [16]. Intraoperatively, the portal vein can thrombose or tear leading to bleeding at the cannulation site. When performed percutaneously, Villiger et al. reported a $>10 \%$ complication rate [17]. Portal venous thrombosis (PVT) has been reported in 3.4\% of patients at the University of Minnesota after TPIAT, and the Alberta group reported PVT in 3.7\% of their allotransplant recipients $[16,18]$. One factor associated with developing PVT is a change in portal pressure above $26 \mathrm{cmH} 20$ during infusion, which limits the volume of islets that can be transplanted [19]. To help mitigate this, there are additional purification steps taken which provide a more concentrated islet fraction and a reduced volume to infuse. These steps add time to the procedure and risks losing some of the islets. This is particularly important because the total transplanted islet mass is a critical determinant of future insulin independence [20].

Finally, monitoring of islet grafts is a challenge in the liver. Percutaneous biopsy is required to evaluate the islets, which has associated risks, and given the islets distribution throughout the liver, a single biopsy may not be representative [21]. Biopsies present procedural risks such as bleeding or biloma. Unfortunately, there are limits regarding the current surrogates used to evaluate for rejection of transplanted islets, and we are lacking an evaluation technique using imaging [22]. 


\section{Metabolic Disadvantages to Intraportal Infusion}

Pancreatic alpha cells produce glucagon in response to hypoglycemia. In the absence of glucagon, epinephrine is released stimulating gluconeogenesis from other substrates like lactate or alanine until the patient has hypoglycemic awareness and consumes carbohydrates. Long term hypoglycemia can lead to neurologic consequences and a decrease in counter-regulatory hormonal cascades $[23,24]$. Hypoglycemic unawareness can be dangerous for patients and impact their quality of life [23]. In islet transplant patients, hypoglycemia is thought to be due to lack of innervation of grafted islets, but a larger impairment was seen in intraportal versus intraperitoneal transplanted pancreatectomized dogs [25].

Pyzdrowski et al. published a pilot study of TPIAT patients with traditional intrahepatic transplants who were insulin independent compared to matched controls. They found a normal glucagon response to arginine stimulation, but no measurable glucagon in response to insulin induced hypoglycemia. However, C peptide levels were decreased, indicating that while transplanted islets stopped secreting insulin in response to hyperglycemia they were unable to mount an appropriate counterregulatory glucagon response [26]. Bellin et al. confirmed this finding in their study of nine TPIAT patients with strictly hepatic islet transplant. They noted that unlike patients who had solely intrahepatic islet grafts, patients who had a portion of islets transplanted to the omentum had normal glucagon responses [27]. Pyzdrowski also noted immunohistological staining for insulin, glucagon and somatostatin on those same patient's liver biopsies suggesting that while alpha cells are engrafting they are not responding normally to physiologic hypoglycemia [26].

Several studies have suggested that the site of transplant may impact transplanted islets' response to hypoglycemia [24, 25]. Bogachus et al. studied patients who experienced postprandial symptoms of hypoglycemia after a mixed meal. Despite being insulin independent, this group had significantly higher glucose excursion after mixed meal consumption followed by significantly lower glucose levels [28]. This compromised glucagon counterregulatory response can lead to clinically significant hypoglycemia in intrahepatic islet transplanted patients regardless of insulin need. One theory suggests that this is due to local glucose production from hepatocytes shielding the transplanted islets from sensing the true systemic hypoglycemia of the patient [25].

Within the liver, islets are exposed to a high proportion of nutrients resulting in hypersecretion of insulin. The paracrine effects of insulin have been reported to lead to hepatic steatosis and glycogen deposits around islets in human and animal models [29]. Bhargava et al. looked at C peptide positive islet transplant patient's magnetic resonance images (MRIs) and found $20 \%$ had steatosis $(n=6)$. C peptide levels in insulin independent patients were higher in those with steatosis and exogenous insulin use on logistic regression was associated with increased odds of steatosis. These findings suggest that steatosis on MRI might be associated with insulin resistance or graft dysfunction [29, 30] Additionally, the resulting hyperglycemia and hyperinsulinemia causes alterations in downstream liver acini. These metabolic changes in acini may be carcinogenic; Dombrowski et al. demonstrated increased development of hepatocellular adenomas and carcinomas in diabetic mice with intrahepatic islet transplants [31]. However, to date, there have been no deaths from liver carcinoma in human patients after alloislet transplantation (citregistry.org). 


\section{Extrahepatic Transplantation Sites}

Contemporary research in the field of extrahepatic transplant has been centered around two main issues:- where should excess islet tissue be placed when portal venous pressure exceeds the safe limit for infusion, and, should all islets be transplanted to extrahepatic sites primarily, bypassing the liver altogether? As previously mentioned, if portal pressures remain prohibitively high during infusion, alternative transplant sites for the remnant islets must be identified because future insulin independence is influenced by the total islet cell mass transplanted [20]. Animal research in TPIAT is limited by our current models. For example, rodents have poor outcomes related to PVT from the very small diameter of their portal vein. The differences between species in islet transplantation has resulted in only a few rodent studies translating to clinical practice. Some of these sites have promise for clinical application while others have only been used on an experimental basis in order to gain further understanding of the physiology of islet transplant [22].

There are multiple characteristics of a suitable transplant site (Table 2). Adequate capacity to accept a significant volume and mass of islets is essential, which is related to the transplant efficacy or the volume of islets required per site to have a significant clinical impact on glycemic control [32]. Revascularization is also essential to engrafted islet survival and function; therefore, the transplant site should have a high oxygen tension to stimulate neoangiogenesis [33]. Drainage of the islet's endocrine products into the portal circulation as opposed to systemic circulation is also desirable. Ideally, there would be minimal risk associated with implanting the islets, with ease of access for future biopsy or imaging. Lastly, avoiding specific conditions of the microenvironment surrounding the islets, such as limiting direct exposure to blood or minimizing the immune response, are key elements to consider.

Table 2 Benefits and limitations of extrahepatic sites.

\begin{tabular}{|l|l|l|l|l|l|l|l|l|}
\hline $\begin{array}{l}\text { Site of } \\
\text { Transplant }\end{array}$ & Capacity & $\begin{array}{l}\text { Transpl } \\
\text { ant } \\
\text { Efficacy }\end{array}$ & $\begin{array}{l}\text { Easy } \\
\text { Access for } \\
\text { Placement }\end{array}$ & $\begin{array}{l}\text { Easy } \\
\text { Evaluation } \\
\text { Post } \\
\text { transplant }\end{array}$ & IBMIR & $\begin{array}{l}\text { Tolerates } \\
\text { unpurified } \\
\text { islets }\end{array}$ & $\begin{array}{l}\text { Rich } \\
\text { vasculature } \\
\text { O2 tension, } \\
\text { nutrients etc }\end{array}$ & $\begin{array}{l}\text { Portal } \\
\text { drainage }\end{array}$ \\
\hline Liver & + & + & + & - & + & - & + & + \\
\hline Spleen & - + & - & + & - & + & + & + & + \\
\hline Kidney & - & + & - & - & - & - & + & - \\
\hline Bone Marrow & - & + & + & + & - & - & + & - \\
\hline Omentum & + & - & + & + & - & + & + & + \\
\hline Peritoneum & + & - & - & - & - & $?$ & - & + \\
\hline Muscle & + & - & + & + & - & - & + & - \\
\hline Subcuticular & + & - & + & + & - & $?$ & - & - \\
\hline GI Submucosa & - & - & + & + & - & $?$ & + & + \\
\hline
\end{tabular}

Capacity: ability to tolerate large volume of cells. Transplant efficacy: low number of islets needed to achieve normoglycemia 


\section{Subcuticular and Intramuscular Injection}

Subcuticular or intramuscular transplant of islets provides easy access for future imaging, biopsy or retrieval of the grafts. There is no intravascular infusion involved for these sites; therefore, there is no associated IBMIR. There are concerns regarding the vulnerability of the grafts to local trauma, and their systemic, rather than portal venous, drainage.

Based on knowledge of intramuscular autotransplantation of parathyroid endocrine tissue [34], intramuscular islet transplantation has been modeled in rodents [35]. Sterkers et al. evaluated intramuscular versus intraportal autotransplants in mini-pigs [36]. When they attempted to follow the principles of parathyroid autotransplant they noted that the blunt dissection resulted in an inflammatory reaction with profound macrophage infiltration, possibly from monocyte stimulation to clear necrotic muscle cells [37]. This prompted a change in technique to direct injection of the islets under the gastrocnemius aponeurosis. Carlsson et al. also reported that injection in large clusters lead to early apoptosis from hypoxia. They recommended diffuse transplantation throughout the muscle and smaller striated muscles with decreased intramuscular pressure [38]. Sterkers's mini-pigs demonstrated islet expression of insulin and glucagon on immunohistochemistry of the intramuscular grafts six months post-transplant. At one month, an acute insulin response to intravenous glucose was seen, but the insulin response was $55 \%$ lower than the pancreatectomized minipigs that received the identical islet mass in the liver [36].

Al-Abdullah et al. compared unpurified islets transplanted to the liver, spleen, skeletal muscle, omental pouch and renal subcapsule of dogs. Four of the five dogs with intramuscular transplant developed necrosis at the transplant site resulting in graft failure [39]. In 1996, a patient who had received a kidney transplant a year prior received a brachioradialis alloislet transplant, however, a biopsy at two weeks post-transplant showed recurrent autoimmune diabetes despite immunosuppression [40]. In 2008, there was a case report of a seven-year-old girl, with severe hereditary pancreatitis requiring a total pancreatectomy, who underwent a successful brachioradialis muscle autoislet transplant [41]. In addition to other case reports in humans [42], Djordjevic et al. injected human fetal islets into the abdominal wall musculature of type 1 diabetics (n=17). Graft function was initially observed with an increase in C-peptide at 90 days post-transplant, however this was followed by a decline in C-peptide levels and no patient achieved insulin independence even after multiple injections [43].

Muscle has higher oxygen tension compared to the liver, and muscular endothelial cells are primed to respond to hypoxia with physiologic angiogenesis as seen in exercise studies [44]. Christoffersson et al. noted that in rat islets, vascular density was similar in striated muscle and the intact pancreas. They found that neutrophils were required to initiate revascularization, and they postulated that this is related to neutrophil release of vascular endothelial growth factor (VEGF) [45]. Svensson et al. also similarly noted intramuscular graft oxygen tension was $70 \%$ of that in native islets in rats, with twice the blood vessel density compared to the renal subcapsular grafts. However, when studying the muscle surrounding transplant islets Svensson et al. noted reduced oxygenation, and a larger portion of connective tissue [44]. This suggests early cell death in the intramuscular grafts with resultant fibrosis. Several studies in rats have shown improved glycemic control with the addition of adjuncts such as IGF-I, or prevascularization with a mesh coated with VEGF or basic fibroblast growth factor [35]. 
The subcuticular space has lower oxygen tension and blood supply than muscle, and allotransplants in both humans and mice have shown islet necrosis [46]. This prompted several groups to explore promoting angiogenesis through stimulating factors or implanting a biocompatible foreign body in rodents. In one such study, a stainless steel mesh was placed in the subcutaneous space of diabetic rats to promote neovasuclarization 40 days before the islets were transplanted. This resulted in normoglycemia with sustained graft function [47]. Overall, the most successful transplants in this area had been pretreated with bioscaffolds and specifically those bioscaffolds that also contained angiogenic factors [35]. Other treatments aimed at improving oxygenation such as hyperbaric oxygen have proven unsuccessful [48]. There have not been any large animal studies looking at islet transplant in the subcuticular space.

In summary, while both sites have been evaluated in small animal models, they have not been compared to intrahepatic transplantation. Despite providing an optimal location for placement and further monitoring of islets, there are the limitations of graft vulnerability and lack of portal drainage. Adjunctive therapies to improve post-transplant oxygenation and angiogenesis may increase the utility of these sites in the future. There is currently a ViaCyte phase $1 /$ II trial to explore a macroencapsulation device placed in the subcuticular space containing pancreatic endodermal cells derived from pluripotent cells (NCT02239354). The pancreatic endoderm cells are from Cyt49 embryonic stem cells, and they mature post transplantation into islet-like cells that have been shown to control blood glucose in rodents. The aim of this trial is to develop an allotransplant that would not require immunosuppression [49].

\section{Bone Marrow}

Bone marrow is a well vascularized, physically protected, broadly distributed and easily accessible site. Rodent studies have shown that both auto and allografts to the bone marrow can result in both insulin and glucagon production, while limiting rejection $[50,51]$. The classical understanding of the immune system implies that the allogenic response is initiated by recognition of non-self antigens; thus, increasing the risk of rejection if the allografts are placed in immediate contact with immunocompetent cells. Conversely, Salazar-Banuelos et al. postulate that bone marrow may encourage antigen presentation leading to tolerance or hyporesponsiveness [51]. It has suggested that bone marrow may be the ideal site for future inquiry into coinjecting islets with immunomodulatory cells such as mesenchymal stem cells or Tregulatory cells. These cells may contribute to the containment of both allo and autoimmune responses, and the bone marrow would provide proximity to islet antigens and the targets of the immunomodulatory cells $[52,53]$. Cantarelli et al. showed in mice that the bone marrow is not a immunoprotective site. In fact, $\mathrm{T}$ cell depleting treatment similar to immunosupression that is used clinically was less effective at preventing rejection in bone marrow [50].

In diabetic mice, bone marrow infusion was superior to the liver in reaching euglycemia and alpha and beta cell fractions, without a difference in glucose metabolism [52]. Islets in this site grew, and were larger 12 months after transplant than when placed [50]. No impact was found of the transplanted islets on the hematopietic activity of bone marrow, even when virus-induced bone marrow aplasia greatly upregulated its function. On biopsy, there was bone resorption and cortical density loss near the grafts [50]. 
A pilot study was performed by Maffi et al. on patients with pancreatogenic diabetes with a contraindication to hepatic transplant $(n=4)$; they received a single autotransplant into the iliac crest bone marrow. The procedure followed the same principles as those used for cord blood cell infusion into the bone marrow of patients with acute leukemia. These patients had detectable levels of C-peptide after islet transplantation, with stable $\mathrm{HbA1c}$, although all required exogenous insulin at one year. On biopsy there was evidence of insulin producing cells without damage to bone structure [54]. The authors highlighted the ease of repeated infusions and graft biopsies, and lack of adverse events. There is an ongoing phase II clinical trial for type 1 diabetics to receive allogenic islets into the liver or bone marrow, but the results are pending (NCT01722682).

\section{Kidney Subcapsule}

While the renal subcapsular space is the most common site for murine model study of islet immune response, pharmaceutical effects and genetic modifications, larger animal studies are limited [55]. In rodent models, kidney subcapsule transplantation results in normoglycemia and expected insulin and glucagon secretion in response to glucose and arginine [56]. Transplant to this site also prevented chronic complications related to diabetes, including nephropathy and ophthalmic complications [57]. Additionally islets can be accessed at a later date for analysis via biopsy. Islet transplantation could also be performed simultaneously with a renal transplant containing the islet graft as some patients may require both [58]. In pancreatectomized canines the number of islets needed to achieve normoglycemia was higher in the kidney subcapsule than the spleen or portal vein [59]. This decreased transplant efficacy poses a particularly difficult obstacle given the kidney's inelasticity and inability to tolerate large volumes [60]. Additionally, the small physical space for islets increases hypoxia.

Small and large animal models have shown poor results [58-60]. One limitation of renal subcapsular islet transplant is later revascularization due to the requirement of perfusion from both the renal artery and renal capsular arteries as seen in rats versus the instant portal vein and earlier hepatic artery revascularization seen in liver islet transplantation [61]. In humans, Cpeptide levels after allotransplant acting as a surrogate for islet survival was seen in both patients who had islets placed in the kidney subcapsule ( 2 of 3 patients) and the portal vein (all 6 patients). A higher islet mass was used in the kidney group. Despite the difference in C peptide levels, neither group had a change in hemoglobin A1c or insulin independence achieved [62].

Another important consideration in this site is the systemic rather than portal drainage, with significantly less insulin reaching its major target organ, the liver. Guan et al. studied normal and diabetic rats with renal subcapsular islet transplants who had systemic renal vein drainage versus those who had a shunt placed to the superior mesenteric vein providing portal drainage. The systemically drained rats had higher insulin response to glucose, insulin resistance and decreased metabolism of insulin compared to portally drained or normal rats [4]. This is likely due to first pass hepatic insulin clearance [5]. Kruszynska et al. found that diabetic rats with renal subcapsular transplant had lower hepatic glycogen stores than those with islets placed in the spleen. This implies that systemic drainage may not lead to enough insulin within the liver, which may be the major limiting factor of transplant to the renal capsule [63]. 


\section{Spleen}

There are several favourable characteristics of islet cell transplantation to the spleen. These include portal venous drainage, easy access intraoperatively, the ability to tolerate unpurified islets and good vascularization. In multiple studies the importance of oxygen tension of a specific site is argued, which was alluded to earlier in the paper [14]. While the oxygen tension and blood flow of native islets is considerably higher in the kidney compared to other sites, Carlsson et al. noted that there was not a difference when compared to spleen, liver or kidney capsule in rats [14].

The spleen's T-regulator cells lead to suppression of effector T cells; and, post transplant inflammatory cytokine levels were significantly lower in the spleen than the liver in mice [64]. Also the spleen may be a reservoir for stem cells that can differentiate into islet progenitor cells adding to islet regeneration [65]. Islets can be transplanted into the spleen through the splenic vein or placed directly into the spleen pulp [64]. This is an important distinction because islets infused through the splenic vein may still be susceptible to IBMIR.

There is conflicting data regarding the use of the spleen for islet transplant in large animal models $[59,64,66]$. Splenic autotransplantation in humans who had a total pancreatectomy was performed at the University of Leicester. While two of the five patients achieved insulin independence for longer than a year, splenic infarction and portal thrombosis limited its application [67]. Du Toit et al. also reported concerning complications such as subcapsular hematoma or perforation, arteriolar thrombosis and intrasplenic necrosis or cavitation [68]. Some authors suggest that clinical outcomes have been limited by technique and complications could be reduced with subcapsular implantation or laparoscopic surgery [64]. In islet autotransplantation, the spleen may be of limited use as a transplant site as a splenectomy is frequently performed with the total pancreatectomy in the modern era.

\section{Intestinal Wall}

The intestinal wall is richly vascularized, with higher oxygen tension, portal venous drainage and the gastric submucosa (GS) has the unique benefit of glycemic sensing. One of the unique attributes of the stomach or duodenum as a transplant site would be endoscopic access [69]. The disadvantages are the high risk of injury to the gastrointestinal tract including: perforation, ischemic, or hemorrhage [70-73]. In rodents, the intestinal wall has shown superior glycometabolism in the gastric submucosa [71], and sustained graft function in the small bowel subserosa space [73]. Other studies have shown improved graft function over other sites in hamsters, and mini-pigs [69, 72].

Endoscopic access provides a novel approach to placing and surveying the islets. Transendoscopic gastric submucosa islet allotransplantion in diabetic pigs had similar reduction in baseline glucose and insulin requirements as those with laparoscopically placed gastric islet transplants [69, 74]. Minimal $C$ peptide was seen 60 minutes after transplant, suggesting minimal islet loss. Of note, there were multiple clinically significant episodes of hypoglycemia amongst these pigs [69].

The mesentery has also been considered given its capacity and rich blood supply. It also follows the same physiologic path of insulin section as the pancreas. If the graft needed to be removed 
the associated intestine would likely have to be sacrificed [64]. Preclinical trials in nonhuman primates investigated using the celiac artery as a transplant site; ultimately, this was shown to be inferior to the portal vein [75]. No human trials with islet transplants to the gastrointestinal tract have been performed to date.

\section{Peritoneum}

The peritoneum has a large capacity for islet cells but has poor transplant efficacy. While it is easily accessible for transplant, peritoneal implants may be challenging to identify or study after transplant [76, 77]. Fritschy et al. found that in streptozotocin diabetic rates with islets transplanted into the peritoneum, normoglycemia and insulin response to intravenous glucose load was directly correlated with the volume of graft used. Even at the highest volume used (8-10 microliters, equivalent to total islet tissue in a normal rat) the glucose and insulin levels on intravenous glucose tolerance testing were not completely normalized. They hypothesized that this may be related to inadequate beta-cell mass and lack of parasympathetic innervation [77].

Wahoff et al. studied dogs who underwent a total pancreatectomy then had either purified islets engrafted intraportally or intraperitoneally and dispersed pancreatic islet tissue intraperitoneally (DPIT). They found that while purified islets transplanted intraperitoneally failed in the first three weeks compared to other groups, the intraperitoneal DPIT group had $67 \%$ graft function at 6 months versus $86 \%$ in the intraportal purified islets with no difference in glucose disposal. They concluded that in addition to being safe and practical the peritoneal cavity may be optimal for tolerating high volume grafts. But, the peritoneum may require a higher number of islets to produce similar function to intraportal grafts (have a low transplant efficacy), as seen in the DPIT which had a higher viable beta-cell mass than purified islets [76].

Given the perionteum's capacity to tolerate large volumes of tissue it has become an area of interest in infusing encapsulated grafts [78]. Encapsulated islets or bioartificial pancreases are future developments that potentially accomplish normoglycemia while also providing immunoprotection from T cells, B cells, macrophages, and NK cells. It would be important to ensure that the site had ease of access for removal of the device or cells if they become infected or fail [21].

In humans, some authors cite concerns about adhesion formation and subsequent risk of ileus, internal hernias and bowel strangulation, though this has not been clinically demonstrated [55]. There have not been human studies utilizing only peritoneal transplant, but it is commonly used for residual islets in TPIAT. Bellin at al noted that five patients with extrahepatic islet transplant, mainly peritoneal, had a normal glucagon response to hypoglycemia while patients with solely hepatic islet transplant did not. This suggests survival of the peritoneal islet cells [27].

\section{Omentum}

The omentum has several advantages as a site for islet transplant, given its lack of volume restrictions, rich vasculature with portal drainage and simplicity of access in the operating room $[79,80]$. There is also less exposure of the islets to blood, possibly reducing both the short-term impact of IBMIR and the longer-term cytokine and endotoxin exposure. A concern for clinical translation includes the theoretical risk of adhesion formation and subsequent bowel obstructions. 
Placing islets in a omental pouch had been shown to maintain normoglycemia in diabetic rats as early as 1983 with a rapid return to diabetic state with removal of the pouch [80]. The Kim group compared kidney, liver, muscle and omental pouch in diabetic mice, they found that the omentum had the glycemic control and kinetics that were closest to controls [32]. Ao et al. studied diabetic dogs with total pancreatectomy and autologous $(n=5)$ or allogenic $(n=12)$ free floating islet transplantation into an omental pouch; $71 \%$ of these dogs become normoglycemic. Additionally, they found that, similar to Wahoff et al. in the peritoneum, the threshold of islet cell mass required to reach the same function was significantly higher ( 2.5 fold compared to the spleen) [81]. Other studies have also confirmed that the while the omentum can achieve glucose control, it has poor transplant efficacy [82].

Berman et al. examined diabetic cynomolgus monkeys, one autologous and five allogenic islet transplants loaded onto a synthetic biodegradable scaffold were positioned in an omental pouch. All of the monkeys had reduced hemoglobin A1c, decreased exogenous insulin requirements and C-peptide levels > $1.0 \mathrm{ng} / \mathrm{ML}$. When the grafts were explanted, they were well granulated and vascularized with insulin-positive islets seen. There was delayed engraftment but similar $\mathrm{C}$ peptide production when compared to solely intrahepatic allogenic transplanted monkeys [83]. Since that time significant study has been dedicated to creating biologic scaffolding systems to provide an extracellular matrix verses transplanting free-floating islet cells [84]. Ao et al. reported that they attempted to perform epiploic arterial infusion of islets in dogs but this led to infarction of the grafts and nonfunction [81].

The omentum may have immunoprivilege [22]. Ao et al. found that intraomental grafts survived longer than intrasplenic grafts after cessation of cyclosporine (CsA) immunosuppression. They postulated that the higher cell-mediated immune effector response in the spleen may accelerate rejection, the lipophilic Csa may be cleared at a lower rater from the fatty omentum leading to higher CSA tissue concentration, and the donor antigen presentation via lymphatics in the omentum versus intravascularly in the spleen may lead to differing sensitization to alloantigens [81].

Omental transplantation has been studied in animal models and in clinical trials which utilized allografts facilitated by a biologic scaffolding [83]. Baidal et al. reported an allotransplant to the omentum in a type 1 diabetic recipient who achieved insulin independence at one year follow up [85]. At the University of Minnesota, islets are occasionally placed into the omentum or peritoneum when prohibitive portal pressures prevent the full volume of islets from being transfused during TPIAT [86]. There is a clinical trial ongoing where a portion of islets are placed in the omentum regardless of portal pressures (NCT03779139). Our technique uses islets that are suspended in plasma derived from the patient. An omental pouch is created and the islets are adhered through adding calcium and thrombin to the plasma or an FDA-approved topical foam hemostatic agent resulting in coagulation to the omentum. The omental edges of the "bowl" are then closed with a running suture and marked with surgical clips for later localization (Figure 2). Closure of the pouch with non-absorbable suture was suggested by Ao et al. who reported early graft failure in a dog autograft recipient whose pouch had opened which they hypothesized led to damage capillaries supplying islets leading to necrosis [81]. 

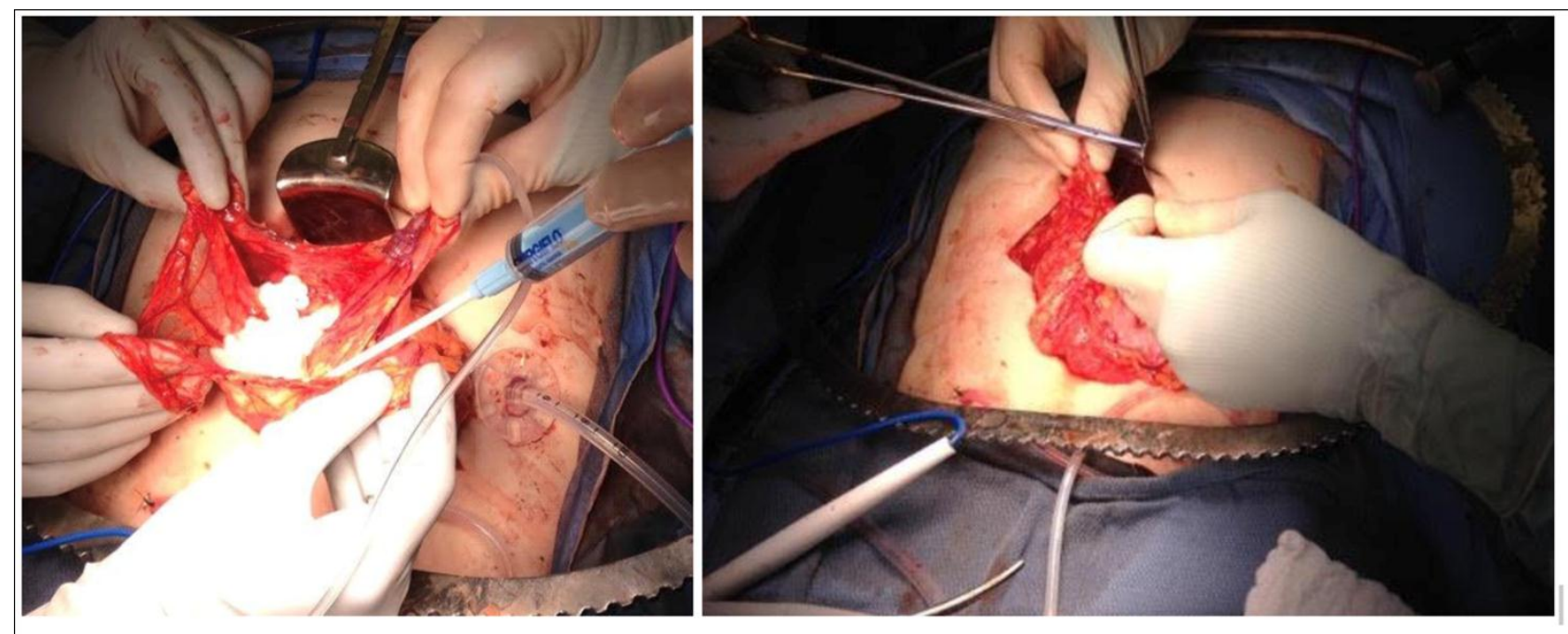

Figure 2 Omental pouch for islet transplantation.

\section{Other Sites}

The thymus, testis, cerebral ventricles and anterior chamber of the eye have been studied as potentially immunoprivileged sites for islet transplant, but at this time have no clinical application $[22,83,87-88]$. The anterior chamber of the eye is undergoing further study in clinical trials. The suppressed immune response was thought to be secondary to lack of lymphatic drainage and cellular infiltration but more recently it is thought to be due to a complex network of immune responses [88]. Immunoprivilege is more likely related to regulatory $\mathrm{T}$ cells or physical cellular shields such as the blood-brain barrier [88-89].

The pancreas is a potential site for allogenic transplant, with the ideal oxygen tension. The procedure to place islets in the pancreatic parenchyma, however, is invasive and could lead to pancreatitis. Theoretically the same autoimmunity that causes type 1 diabetes could affect the islets in allotransplantation [22]. Rodent models for islet transplant to the pancreas have yielded positive results, however no large animal or human studies have been performed [90].

\section{Conclusions}

The current predominant location for transplanting islet cells is the liver via the portal venous system. Despite the relative success of this site for allo- and auto-transplantation over the last several decades, there remain several disadvantages to this site. Portal hypertension, portal vein thrombosis, bleeding,low oxygen tension, IBMIR, inadequate alpha cell function, and delays in neovascularization are factors that continue to drive researchers to explore alternative extrahepatic sites for islet transplantation. These factors and others lend to the challenge in finding a better alternative, which has limited the clinical translation of a clear solution. Ongoing clinical studies are summarized in Table 3. 
Table 3 Overview of ongoing clinical testing for alternative islet transplants.

\begin{tabular}{|c|c|c|c|c|}
\hline Trial ID & Site & Study Type & Study Location & Unique features \\
\hline NCT01722682 & Bone Marrow & Phase $1 / 2$ & $\begin{array}{l}\text { San Raffaele Scientific } \\
\text { Institute, Milan, Italy }\end{array}$ & vs. Liver \\
\hline \multirow[t]{2}{*}{ NCT02213003 } & Omentum & Phase $1 / 2$ & $\begin{array}{l}\text { University of Miami / } \\
\text { Diabetes Research } \\
\text { institute }\end{array}$ & Autologous plasma \\
\hline & Omentum & Phase $1 / 2$ & $\begin{array}{l}\text { University Hospital } \\
\text { Brussels, Brussels, } \\
\text { Belgium }\end{array}$ & \\
\hline NCT02821026 & Omentum & Phase $1 / 2$ & $\begin{array}{l}\text { Clinical Islet Transplant } \\
\text { Program } \\
\text { Edmonton, Alberta, } \\
\text { Canada }\end{array}$ & $\begin{array}{l}\text { Combined study with } \\
\text { U Miami }\end{array}$ \\
\hline NCT02803905 & Omentum & Phase 2 & University of Milan & vs. portal vein \\
\hline NCT03779139 & Omentum & Pilot & University of Minnesota & \\
\hline$\frac{\text { NCT01571817 }}{\text { NCT02402439 }}$ & $\begin{array}{l}\text { Gastric } \\
\text { Submucosa }\end{array}$ & Phase 1 & $\begin{array}{l}\text { University of California, } \\
\text { San Francisco }\end{array}$ & $\begin{array}{l}\text { After kidney } \\
\text { transplant }\end{array}$ \\
\hline NCT00790257 & $\begin{array}{l}\text { Subcutaneous } \\
\text { space }\end{array}$ & Phase $1 / 2$ & $\begin{array}{l}\text { Cliniques universitaires } \\
\text { Saint Luc Université } \\
\text { Catholique de Louvain }\end{array}$ & $\begin{array}{l}\text { Encapsulated on } \\
\text { monolayer device }\end{array}$ \\
\hline \multirow[t]{4}{*}{ NCT02064309 } & $\begin{array}{l}\text { Subcutaneous } \\
\text { space }\end{array}$ & Phase $1 / 2$ & $\begin{array}{l}\text { Uppsala University } \\
\text { Hospital }\end{array}$ & $\begin{array}{l}\text { Implantable Beta-Air } \\
\text { device }\end{array}$ \\
\hline & Subcutaneous & Phase $1 / 2$ & $\begin{array}{l}\text { Diabetes \& Glandular } \\
\text { Disease Research } \\
\text { Associates and Christus } \\
\text { Sant Rosa Transplant, San } \\
\text { Antonio, Texas, USA }\end{array}$ & PEG- encapsulated \\
\hline & Subcutaneous & Phase 1 & $\begin{array}{l}\text { University Clinical } \\
\text { Hospital Saint-Luc, } \\
\text { Brussels, Belgium }\end{array}$ & $\begin{array}{l}\text { Encapsulated in } \\
\text { monolayer cellular } \\
\text { device }\end{array}$ \\
\hline & Subcutaneous & Phase $1 / 2$ & $\begin{array}{l}\text { University of California at } \\
\text { San Diego, University of } \\
\text { Alberta Hospital }\end{array}$ & $\begin{array}{l}\text { Macroencapsulated } \\
\text { device of pancreatic } \\
\text { endodermal cells }\end{array}$ \\
\hline
\end{tabular}




\begin{tabular}{|c|c|c|c|c|}
\hline NCT01379729 & $\begin{array}{l}\text { Peritoneal } \\
\text { cavity }\end{array}$ & Phase $1 / 2$ & $\begin{array}{l}\text { Ziekenhuis } \\
\text { Brussel/Ziekenhuizen } \\
\text { LeuvenBelgium }\end{array}$ & Alginate encapsulated \\
\hline & Peritoneum & Phase 1 & $\begin{array}{l}\text { University of Perugia, } \\
\text { Perugia, Italy }\end{array}$ & $\begin{array}{l}\text { PLO-alginate- } \\
\text { encapsulated }\end{array}$ \\
\hline \multirow[t]{2}{*}{ NCT01967186 } & Muscle & Phase $1 / 2$ & $\begin{array}{l}\text { Nordic Network for } \\
\text { clinical islet } \\
\text { transplantation }\end{array}$ & $\begin{array}{l}\text { In kidney transplant } \\
\text { Vs. Intraportal, some } \\
\text { with auto MSC }\end{array}$ \\
\hline & Muscle & Pilot & $\begin{array}{l}\text { Karolinska Institute, } \\
\text { Stockholm, Sweden; } \\
\text { Uppsala University } \\
\text { Hospital, Sweden; and } \\
\text { University of Lille, France }\end{array}$ & \\
\hline$\frac{\text { NCT01652911 }}{\text { NCT03513939 }}$ & Subcutaneous & Phase $1 / 2$ & University of Alberta & Cell pouch $\left({ }^{\mathrm{TM}}\right)$ \\
\hline NCT02916680 & $\begin{array}{l}\text { Anterior } \\
\text { chamber of } \\
\text { the eye }\end{array}$ & & $\begin{array}{l}\text { University Hospital, } \\
\text { Basel, Switzerland }\end{array}$ & $\begin{array}{l}\text { Only severely } \\
\text { impaired diabetic } \\
\text { eyes }\end{array}$ \\
\hline NCT02846571 & $\begin{array}{l}\text { Anterior } \\
\text { chamber of } \\
\text { the eye }\end{array}$ & Phase $1 / 2$ & University of Miami, FL & \\
\hline NCT006925 & $\begin{array}{l}\text { Simultaneous } \\
\text { Islet-Kidney }\end{array}$ & Phase $1 / 2$ & $\begin{array}{l}\text { Fuzhou General Hospital, } \\
\text { China }\end{array}$ & \\
\hline
\end{tabular}

MSC: mesenchymal stem cells PLO: poly-L-ornithine PEG: polyethylene glycol

\section{Author Contributions}

AJC and GJB designed the study. AJC, KRM, MES, SM, and MDB aided in writing and critical revision. GJB also aided in critical revision.

\section{Funding}

Research by Drs. Beilman, Skube and McEachron are funded by the NIH (T32DK108733) and Drs. Beilman and Coughlan are funded by the DOD (W81XWH18106872).

\section{Competing Interests}

The authors have declared that no competing interests exist. 


\section{References}

1. Kemp CB, Knight MJ, Scharp DW, Ballinger WF, Lacy PE. Effect of transplantation site on the results of pancreatic islet isografts in diabetic rats. Diabetologia. 1973; 9: 486-491.

2. Sutherland DERR, Radosevich DM, Bellin MD, Hering BJ, Beilman GJ, Dunn TB, et al. Total pancreatectomy and islet autotransplantation for chronic pancreatitis. J Am Coll Surg. 2012; 214: 409-424.

3. Chinnakotla S, Radosevich DM, Dunn TB, Bellin MD, Freeman ML, Schwarzenberg SJ, et al. Long-term outcomes of total pancreatectomy and islet auto transplantation for hereditary/genetic pancreatitis. J Am Coll Surg. 2014; 218: 530-543.

4. Guan J, Zucker PF, Behme MT, Zhong R, Atkison P, Dupré J. Insulin resistance prevented by portal delivery of insulin in rats with renal subcapsular islet grafts. Diabetes. 1997; 46: 372378.

5. Diem P, Abid M, Redmon JB, Sutherland DER, Robertson RP. Systemic venous drainage of pancreas allografts as independent cause of hyperinsulinemia in type I diabetic recipients. Diabetes. 1990; 39: 534-540.

6. Meier JJ, Hong-McAtee I, Galasso R, Veldhuis JD, Moran A, Hering BJ, et al. Intrahepatic transplanted islets in humans secrete insulin in a coordinate pulsatile manner directly into the liver. Diabetes. 2006; 55: 2324-2332.

7. Scharp DWDW, Lacy PEPE, Santiago JVJV, Mccullough CSCS, Weide LGLG, Falqui L, et al. Insulin independence after islet transplantation into type I diabetic patient. Diabetes. 1990; 39: 515-518.

8. Najarian JS, Sutherland DER, Baumgartner D, Burke B, Rynasiewicz JJ, Matas AJ, et al. Total or near total pancreatectomy and islet autotransplantation for treatment of chronic pancreatitis. Ann Surg. 1980; 192: 526-542.

9. Shapiro AMJ, Lakey JRT, Ryan EA, Korbutt GS, Toth E, Warnock GL, et al. Islet Transplantation in Seven Patients with Type 1 Diabetes Mellitus Using a Glucocorticoid-Free Immunosuppressive Regimen. N Engl J Med. 2000; 343: 230-238.

10. Naziruddin B, Iwahashi S, Kanak MA, Takita M, Itoh T, Levy MF. Evidence for instant bloodmediated inflammatory reaction in clinical autologous islet transplantation. Am J Transplant. 2014; 14: 428-437.

11. Ishiyama K, Rawson J, Omori K, Mullen Y. Liver natural killer cells play a role in the destruction of islets after intraportal transplantation. Transplantation. 2011; 91: 952-960.

12. Tanemura $M$, Ohmura $Y$, Deguchi $T$, MacHida $T$, Tsukamoto $R$, Wada $H$, et al. Rapamycin causes upregulation of autophagy and impairs islets function both in vitro and in vivo. Am J Transplant. 2012; 12: 102-114.

13. Desai NM, Goss JA, Deng S, Wolf BA, Markmann E, Palanjian M, et al. Elevated portal vein drug levels of sirolimus and tacrolimus in islet transplant recipients: Local immunosuppression or islet toxicity. Transplantation. 2003; 76: 1623-1625.

14. Carlsson PO, Palm F, Andersson A, Liss P. Markedly decreased oxygen tension in transplanted rat pancreatic islets irrespective of the implantation site. Diabetes. 2001; 50: 489-495.

15. Olsson R, Olerud J, Pettersson U, Carlsson PO. Increased numbers of low-oxygenated pancreatic islets after intraportal islet transplantation. Diabetes. 2011; 60: 2350-2353.

16. Wilhelm JJ, Bellin MD, Dunn TB, Balamurugan AN, Pruett TL, Radosevich DM, et al. Proposed 
thresholds for pancreatic tissue volume for safe intraportal islet autotransplantation after total pancreatectomy. Am J Transplant. 2013; 13: 3183-3191.

17. Villiger P, Ryan EA, Owen R, O'Kelly K, Oberholzer J, Saif F Al, et al. Prevention of bleeding after islet transplantation: Lessons learned from a multivariate analysis of 132 cases at a single institution. Am J Transplant. 2005; 5: 2992-2998.

18. Kawahara T, Kin T, James Shapiro AM, Shapiro AMJ, James Shapiro AM. A comparison of islet autotransplantation with allotransplantation and factors elevating acute portal pressure in clinical islet transplantation. J Hepatobiliary Pancreat Sci. 2012; 19: 281-288.

19. Chinnakotla S, Beilman GJ, Dunn TB, Bellin MD, Freeman ML, Radosevich DM, et al. Factors predicting outcomes after a total pancreatectomy and islet autotransplantation lessons learned from over 500 cases. Ann Surg. 2015; 262: 610-622.

20. Bellin MD, Balamurugan AN, Pruett TL, Sutherland DER. No islets left behind: Islet autotransplantation for surgery-induced diabetes. Curr Diab Rep. 2012; 12: 580-586.

21. Sakata N, Aoki T, Yoshimatsu G, Tsuchiya HH, Hata T, Katayose Y, et al. Strategy for clinical setting in intramuscular and subcutaneous islet transplantation. Diabetes Metab Res Rev. 2014; 26: 446-447.

22. Rajab A. Islet Transplantation: Alternative Sites. Curr Diab Rep. 2010; 10: 332-337.

23. Cryer PE. Hierarchy of physiological responses to hypoglycemia: Relevance to clinical hypoglycemia in type I (insulin dependent) diabetes mellitus. Horm Metab Res. 1997; 29: 9296.

24. Zhou H, Zhang T, Bogdani M, Oseid E, Parazzoli S, Vantyghem MC, et al. Intrahepatic glucose flux as a mechanism for defective intrahepatic islet $\alpha$-cell response to hypoglycemia. Diabetes. 2008; 57: 1567-1574.

25. Gupta V, Wahoff DC, Rooney DP, Poitout V, Sutherland DER, Kendall DM, et al. The defective glucagon response from transplanted intrahepatic pancreatic islets during hypoglycemia is transplantation site-determined. Diabetes. 1997; 46: 28-33.

26. Pyzdrowski KL, Kendall DM, Halter JB, Nakhleh RE, Sutherland DER, Robertson RP. Preserved Insulin Secretion and Insulin Independence in Recipients of Islet Autografts. N Engl J Med. 1992; 327: 220-226.

27. Bellin MD, Parazzoli S, Oseid E, Bogachus LD, Schuetz C, Patti ME, et al. Defective glucagon secretion during hypoglycemia after intrahepatic but not nonhepatic islet autotransplantation. Am J Transplant. 2014; 14: 1880-1886.

28. Bogachus LD, Bellin MD, Vella A, Paul Robertson R. Deficient Glucagon Response to Hypoglycemia during a Mixed Meal in Total Pancreatectomy/Islet Autotransplantation Recipients. J Clin Endocrinol Metab. 2018; 103: 1522-1529.

29. Bhargava R, Senior PA, Ackerman TE, Ryan EA, Paty BW, Lakey JRT, et al. Prevalence of Hepatic Steatosis after Islet Transplantation and Its Relation to Graft Function. Diabetes. 2004; 53: 1311-1317.

30. Poitout V, Amyot J, Semache M, Zarrouki B, Hagman D, Fontés G. Glucolipotoxicity of the pancreatic beta cell. Biochimica et Biophysica Acta - Molecular and Cell Biology of Lipids. 2010; 1801: 289-298.

31. Dombrowski F, Mathieu C, Evert M. Hepatocellular neoplasms induced by low-number pancreatic islet transplants in autoimmune diabetic BB/Pfd rats. Cancer Res. 2006; 66: 18331843. 
32. Kim H II, Yu JE, Park CG, Kim SJ. Comparison of four pancreatic islet implantation sites. J Korean Med Sci. 2010; 25: 203-210.

33. Ballian N, Brunicardi FC. Islet vasculature as a regulator of endocrine pancreas function. World J Surg. 2007; 31: 705-714.

34. Lo CY, Tam SC. Parathyroid autotransplantation during thyroidectomy: Documentation of graft function. Arch Surg. 2001; 136: 1381-1385.

35. Witkowski P, Sondermeijer H, Hardy MA, Woodland DC, Lee K, Bhagat G, et al. Islet grafting and imaging in a bioengineered intramuscular space. Transplantation. 2009; 88: 1065-1074.

36. Sterkers A, Hubert T, Gmyr V, Torres F, Baud G, Delalleau N, et al. Islet survival and function following intramuscular autotransplantation in the minipig. Am J Transplant. 2013; 13: 891898.

37. Arnold L, Henry A, Poron F, Baba-Amer $\mathrm{Y}$, van Rooijen N, Plonquet $A$, et al. Inflammatory monocytes recruited after skeletal muscle injury switch into antiinflammatory macrophages to support myogenesis. J Exp Med. 2007; 204: 1057-1069.

38. Christoffersson G, Carlsson PO, Phillipson M. Intramuscular islet transplantation promotes restored islet vascularity. Islets. 2011; 3: 69-71.

39. Al-Abdullah IH, Anil Kumar MS, Kelly-Sullivan D, Abouna GM. Site for unpurified islet transplantation is an important parameter for determination of the outcome of graft survival and function. Cell Transplant. 1995; 4: 297-305.

40. Stegall MD, Lafferty KJ, Kam I, Gill RG. Evidence of recurrent autoimmunity in human allogeneic islet transplantation. Transplantation. 1996; 61: 1272-1274.

41. Rafael $E$, Tibell A, Rydén $M$, Lundgren $T$, Sävendahl $L$, Borgström $B$, et al. Intramuscular autotransplantation of pancreatic islets in a 7-year-old child: A 2-year follow-up. Am J Transplant. 2008; 8: 458-462.

42. Dardenne S, Sterkers A, Leroy C, da Mata L, Zerbib P, Pruvot FR, et al. Laparoscopic spleenpreserving distal pancreatectomy followed by intramuscular autologous islet transplantation for traumatic pancreatic transection in a young adult. J Pancreas. 2012; 13: 285-288.

43. Djordjevic PB, Lalic N, Bumbasirevic V, Jotic A, Paunovic I, Colovic R, et al. Human fetal islet transplantation in type 1 diabetics: Comparison of immunological effects between multiple implantation regimens. Transplant Proc. 2005; 37: 4440-4445.

44. Svensson J, Lau J, Sandberg M, Carlsson PO. High vascular density and oxygenation of pancreatic islets transplanted in clusters into striated muscle. Cell Transplant. 2011; 20: 783788.

45. Christoffersson G, Henriksnäs J, Johansson L, Rolny C, Ahlström H, Caballero-Corbalan J, et al. Clinical and experimental pancreatic islet transplantation to striated muscle: Establishment of a vascular system similar to that in native islets. Diabetes. 2010; 59: 2569-2578.

46. Scharp DW, Swanson CJ, Olack BJ, Latta PP, Hegre OD, Doherty EJ, et al. Protection of encapsulated human islets implanted without immunosuppression in patients with type I or type II diabetes and in nondiabetic control subjects. Diabetes. 1994; 43: 1167-1170.

47. Pileggi A, Molano RD, Ricordi C, Zahr E, Collins J, Valdes R, et al. Reversal of diabetes by pancreatic islet transplantation into a subcutaneous, neovascularized device. Transplantation. 2006; 81: 1318-1324.

48. Juang JH, Hsu BRS, Kuo $\mathrm{CH}$. Islet transplantation at subcutaneous and intramuscular sites. Transplant Proc. 2005; 37: 3479-3481. 
49. Schulz TC. Concise Review: Manufacturing of Pancreatic Endoderm Cells for Clinical Trials in Type 1 Diabetes. Stem Cells Transl Med. 2015; 4: 927-931.

50. Cantarelli E, Melzi R, Mercalli A, Sordi V, Ferrari G, Lederer CW, et al. Bone marrow as an alternative site for islet transplantation. Blood. 2009; 114: 4566-4574.

51. Salazar-Bañuelos A, Wright JR, Sigalet D, Benítez-Bribiesca L. Pancreatic islet transplantation into the bone marrow of the rat. Am J Surg. 2008; 195: 674-678;

52. Cantarelli E, Citro A, Pellegrini S, Mercalli A, Melzi R, Dugnani E, et al. Transplant site influences the immune response after islet transplantation: Bone marrow versus liver. Transplantation. 2017; 101: 1046-1055.

53. Battaglia M, Stabilini A, Migliavacca B, Horejs-Hoeck J, Kaupper T, Roncarolo M-G. Rapamycin Promotes Expansion of Functional CD4+CD25+FOXP3+ Regulatory T Cells of Both Healthy Subjects and Type 1 Diabetic Patients. J Immunol. 2006; 177: 8338-8347.

54. Maffi P, Balzano G, Ponzoni M, Nano R, Sordi V, Melzi R, et al. Autologous pancreatic islet transplantation in human bone marrow. Diabetes. 2013; 62: 3523-3531.

55. Van Der Windt DJ, Echeverri GJ, Ijzermans JNM, Cooper DKC. The choice of anatomical site for islet transplantation. Cell Transplant. 2008; 17: 1005-1014.

56. Weitgasser R, Davalli AM, Capotorto JV, Finegood DT, Bonner-Weir S, Weir GC. Islet transplantation in diabetic Lewis rats--a comparison of the transplantation sites kidney and spleen capsule. Acta Med Austriaca. 1996; 23: 156-159.

57. Ar'rajab A, Ahrén B, Alumets J, Lögdberg L, Bengmark S. Islet transplantation to the renal subcapsular space improves late complications in streptozotocin-diabetic rats. Eur Surg Res. 1990; 22: 270-278.

58. Rajab A, Buss J, Diakoff E, Hadley GA, Osei K, Ferguson RM. Comparison of the portal vein and kidney subcapsule as sites for primate islet autotransplantation. Cell Transplant. 2008; 17: 1015-1023.

59. Kaufman DB, Morel P, Field MJ, Munn SR, Sutherland DE. Purified canine islet autografts. Functional outcome as influenced by islet number and implantation site. Transplantation. 1990; 50: 385-391.

60. Gray DWR, Sutton R, McShane P, Peters M, Morris PJ. Exocrine contamination impairs implantation of pancreatic islets transplanted beneath the kidney capsule. J Surg Res. 1988; 45: 432-442.

61. Kin T, Rajotte RV, Korbutt GS. Reassessment of the vascularization of renal subcapsular islet grafts. Pancreas. 2004; 29: e59-e63.

62. Jindal RM, Sidner RA, McDaniel HB, Johnson MS, Fineberg SE. Intraportal vs kidney subcapsular site for human pancreatic islet transplantation. Transplant Proc. 1998; 30: 398399.

63. Kruszynska YT, Home PD, Alberti KG. Comparison of portal and peripheral insulin delivery on lipid metabolism in streptozocin-diabetic rats. Diabetes. 1985; 34: 611-616.

64. Itoh T, Nishinakamura $\mathrm{H}$, Kumano $\mathrm{K}$, Takahashi $\mathrm{H}$, Kodama $\mathrm{S}$. The spleen is an ideal site for inducing transplanted islet graft expansion in mice. PLoS One. 2017; 12: e0170899.

65. Kodama S, Kühtreiber W, Fujimura S, Dale EA, Faustman DL. Islet Regeneration during the Reversal of Autoimmune Diabetes in NOD Mice. Science. 2003; 302: 1223-1227.

66. Sutton R, Gray DWR, Burnett M, McShane P, Turner RC, Morris PJ. Metabolic function of intraportal and intrasplenic islet autografts in cynomolgus monkeys. Diabetes. 1989; 38: 182- 
184.

67. White SA, London NJM, Johnson PRV, Davies JE, Pollard C, Contractor HH, et al. The risks of total pancreatectomy and splenic islet autotransplantation. Cell Transplant. 2000; 9: 19-24.

68. DuToit DF, Reece-Smith H, McShane P, Denton T, Morris PJ. Effect of cyclosporin a on allotransplanted pancreatic fragments to the spleen of totally pancreatectomized dogs. Transplantation. 1982; 33: 302-307.

69. Echeverri GJ, McGrath K, Bottino R, Hara H, Dons EM, Van Der Windt DJ, et al. Endoscopic gastric submucosal transplantation of islets (ENDO-STI): Technique and initial results in diabetic pigs. Am J Transplant. 2009; 9: 2485-2496.

70. Yin Z zeng, Wang $S$ sen, Li Q, Huang $Y$, Chen L, Chen G, et al. Gastric submucosa is inferior to the liver as transplant site for autologous islet transplantation in pancreatectomized diabetic Beagles. J Huazhong Univ Sci Technol - Med Sci. 2016; 36: 529-533.

71. Liu X, Zhang J, Li Y, Hu S, Zhang G, Wang L. Gastric subserous space islet transplantation: Techniques and initial results in diabetic inbred Lewis rats. Ann Transplant. 2014; 19: 331-336.

72. Tchervenivanov N, Yuan S, Lipsett M, Agapitos D, Rosenberg L. Morphological and functional studies on submucosal islet transplants in normal and diabetic hamsters. Cell Transplant. 2002; 11: 529-537.

73. Sageshima J, Kirchhof N, Shibata S, Hiraoka K, Sutherland DERR, Hering BJ. Small bowel subserosal space as a site for islet transplantation and local drug delivery. Transplant Proc. 2001; 33: 1710.

74. Tanaka T, Fujita M, Bottino R, Piganelli JD, McGrath K, Li J, et al. Endoscopic biopsy of islet transplants in the gastric submucosal space provides evidence of islet graft rejection in diabetic pigs. Islets. 2016; 8: 1-12.

75. Hirshberg B, Montgomery S, Wysoki MG, Xu H, Tadaki D, Lee J, et al. Pancreatic islet transplantation using the nonhuman primate (Rhesus) model predicts that the portal vein is superior to the celiac artery as the islet infusion site. Diabetes. 2002; 51: 2135-2140.

76. Wahoff DC, Sutherland DE, Hower CD, Lloveras JK, Gores PF. Free intraperitoneal islet autografts in pancreatectomized dogs--impact of islet purity and posttransplantation exogenous insulin. Surgery. 1994; 116: 742-750.

77. Fritschy WM, Van Straaten JFM, Vos P De, Strubbe JH, Wolters GHJ, Schilfgaarde R Van. The efficacy of intraperitoneal pancreatic islet isografts in the reversal of diabetes in rats. Transplantation. 1991; 52: 777-783.

78. Qi M. Transplantation of Encapsulated Pancreatic Islets as a Treatment for Patients with Type 1 Diabetes Mellitus. Adv Med. 2014; 2014: 1-15.

79. Bartholomeus K, Jacobs-Tulleneers-Thevissen D, Shouyue S, Suenens K, In'T Veld PA, Pipeleers-Marichal $M$, et al. Omentum is better site than kidney capsule for growth, differentiation, and vascularization of immature porcine $\beta$-cell implants in immunodeficient rats. Transplantation. 2013; 96: 1026-1033.

80. Yasunami Y, Lacy PE, Finke EH. A new site for islet transplantation-A peritoneal-omental pouch. Transplantation. 1983; 36: 181-182.

81. Ao Z, Matayoshi K, Lakey JRT, Rajotte RV, Warnock GL. Survival and function of purified islets in the omental pouch site of outbred dogs. Transplantation. 1993; 56: 524-529.

82. Kin T, Korbutt GS, Rajotte R V. Survival and metabolic function of syngeneic rat islet grafts transplanted in the omental pouch. Am J Transplant. 2003; 3: 281-285. 
83. Berman DM, O'Neil JJ, Coffey LCK, Chaffanjon PCJ, Kenyon NMS, Ruiz P, et al. Long-term survival of nonhuman primate islets implanted in an omental pouch on a biodegradable scaffold. Am J Transplant. 2009; 9: 91-104.

84. Blomeier $H$, Zhang $X$, Rives $C$, Brissova $M$, Hughes $E$, Baker $M$, et al. Polymer scaffolds as synthetic microenvironments for extrahepatic islet transplantation. Transplantation. 2006; 82: 452-459.

85. Baidal DA, Ricordi C, Berman DM, Alvarez A, Padilla N, Ciancio G, et al. Bioengineering of an Intraabdominal Endocrine Pancreas. N Engl J Med. 2017; 376: 1887-1889.

86. Stice MJ, Dunn TB, Bellin MD, Skube ME, Beilman GJ. Omental pouch technique for combined site islet autotransplantation following total pancreatectomy. Cell Transplant. 2018; 27: 15611568.

87. Posselt AM, Barker CF, Tomaszewski JE, Markmann JF, Choti MA, Naji A. Induction of donorspecific unresponsiveness by intrathymic islet transplantation. Science. 1990; 249: 1293-1295.

88. Kaur G, Mital P, Dufour JM. Testisimmune privilege - Assumptions versus facts. Anim Reprod. 2013; 10: 3-15.

89. Larocque D, Sanderson NSR, Bergeron J, Curtin JF, Girton J, Wibowo M, et al. Exogenous fmslike tyrosine kinase 3 ligand overrides brain immune privilege and facilitates recognition of a neo-antigen without causing autoimmune neuropathology. Proc Natl Acad Sci. 2010; 107: 14443-14448.

90. Stagner J, Ahren B, Sundler F, White K. Reconstructing the Pancreas: Restoration of Normoglycemia, Exocrine Function, and Islet Innervation by Islet Transplantation to the Pancreas. Transplant Proc. 2008; 40: 452-454.

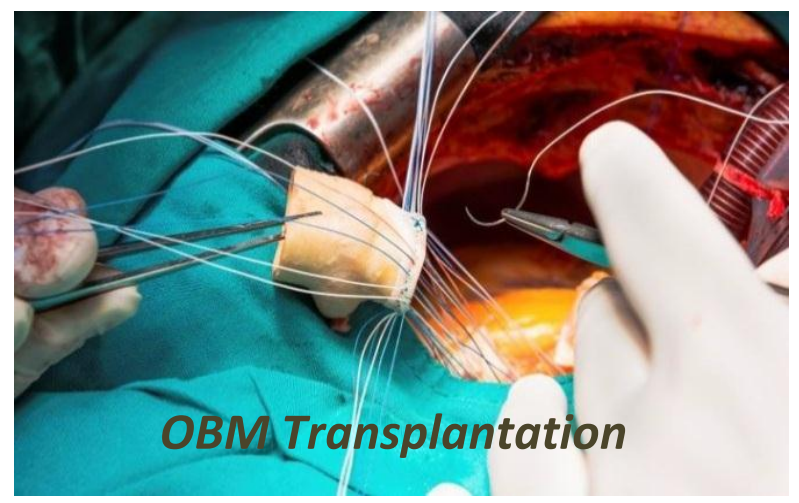

Enjoy OBM Transplantation by:

1. Submitting a manuscript

2. Joining in volunteer reviewer bank

3. Joining Editorial Board

4. Guest editing a special issue

For more details, please visit:

http://www.lidsen.com/journals/transplantation 